\title{
Asas Keterbukaan dalam Penanganan Perkara Perbankan di Indonesia
}

\author{
Suwari Akhmaddhian, Dela Agustin \\ Fakultas Hukum, Universitas Kuningan, Indonesia \\ Email : delaagustin@gmail.com
}

\begin{abstract}
The principle of openness is very much needed in all aspects of life, both in married life, in the smallest organization it must have the principle of openness so that there is trust from those who lead with their leaders. Openness is a wise attitude, humble, fair, accept the opinions of others, forgive the mistakes of others with grace, tolerance, tattwamasi, do something in accordance with what is enjoyed and said. Openness is also needed to create a sense of harmony in social life because with openness someone will want to accept all the advantages possessed by others and will not assume that other people are always underneath.
\end{abstract}

Keywords: The principle of openness, banking, banking matters

\begin{abstract}
Abstrak
Asas keterbukaan sangat diperlukan dalam segala aspek kehidupan, baik dalam kehidupan berumah tangga, dalam organisasi sekecil apapun haruslah memiliki asas keterbukaan agar ada kepercayaan dari yang memimpin dengan pemimpinnya. Keterbukaan merupakan sikap bijak, rendah hati, adil, menerima pendapat oramng lain, memaafkan kesalahan orang lain dengan lapang dada, bertoleransi, tattwamasi, melakukan sesuatu yang sesuai dengan apa yang dinikmati dan dikatakannya. Keterbukaan juga diperlukan untuk menciptakan rasa keharmonisan dalam kehidupan bermasyarakat karena dengan keterbukaan sesorang akan mau menerima segala sesuatu kelebihan yang dimiliki oleh orang lain dan tidak akan menganggap orang lain tersebut selalu ada di bawahnya.
\end{abstract}

Kata Kunci : Asas keterbukaan, perbankan, perkara perbankan

\section{PENDAHULUAN}

Masyarakat Indonesia merupakan masyarakat majemuk yang terdiri dari berbagai suku bangsa,ras, agama, dan budaya. Dimana keragaman yang dimiliki Bangsa Indonesia merupakan suatu kekayaan alam dan budaya yang potensial dan dapat jadi modal dasar dalam pembangunan. Perbedaan itu juga dapat menimbulkan perpecahan dan muncul perbedaan pendapat. Untuk dapat mengantisipasi perpecahan maka keterbukaan harus ditanamkan dan dipelihara dengan baik. Keterbukaan dapat diartikan sebagai keadaan yang memungkinkan ketersediaan informasi yang dapat diberikan dan didapatkan oleh masyarakat luas. Keterbukaan menjadikan berbagai informasi dapat diketahui masyarakat. Sikap terbuka adalah sikap untuk bersedia memberitahukan dan sikap untuk bersedia menerima pengetahuan atau informasi dari pihak lain.

Sikap terbuka dapat dimiliki oleh setiap orang, masyarakat dan warga negara. Orang yang terbuka akan mendapatkan informasi dan pengetahuan, mempererat persaudaraan, serta memperkuat persatuan. Sifat yang serba tertutup justru dapat merugikan diri sendiri.Keterbukaan merupakan suatu kondisi yang memungkinkan partisipasi masyarakat dalm kehidupan bernegara. Salah satu ciri pemerintahan demokratis adalah 
Logika : Journal of Multidisciplinary Studies, p-ISSN 2085-9970. e-ISSN 2715-4505

Vol. 10 Nomor 02 Desember 2019. 94-99

keterbukaan. Keterbukaan menjadi bukti bahwa pemerintah sanggup bertanggung jawab terhadap kegiatan yang dilakukannya terhadap rakyat ${ }^{1}$.

Untuk memenuhi kehidupan yang sesuai dengan tuntutan reformasi satu diantaranya harus diadakan transparasi dan jaminan keadilan disegala bidang kehidupan kalau ingin mempertahankan kelangsungan hidup bangsa Indonesia. Salah satu hal yang bisa mewujudkan hal itu adalah dengan selalu mengembangkan sikap keterbukaan antara warga Indonesia di dalam melaksanakan kehidupannya. Di dalam kehidupan masyarakat sangat sering kita jumpai tidak adanya rasa atau sifat saling keterbukaan sengan anggota masyarakat sehingga sering terjadi penyimpangan-penyimpangan diantaranya praktek korupsi, kolusi, dan nepotisme. Berdasarkan latar belakang diatas, adapun rumusan masalah dalam penelitian ini adalah: Bagaimana dengan dasar hukum dan implementasi asas keterbukaan?

\section{METODE PENELITIAN}

Metode penelitian yang digunakan oleh penulis adalah yuridis normatif, dengan alat pengumpul data melalui studi kepustakaan yaitu studi dokumentasi peraturan perundang-undangan serta artikel-artikel yang terkait dengan penelitian ini.

\section{PEMBAHASAN}

Dalam teori demokrasi pemerintahan yang terbuka adalah suatu hal yang esensial atau penting terutama akses bebas setiap warga negara terhadap berbagai sumber informasi, supaya tidak terjadi saling curiga antar individu, masyarakat dengan pemerintah. Keterbukaan dalam penyelenggaraan yaitu setiap kebijakan haruslah jelas, tidak dilakukan secara sembunyi, rahasia tetapi perencanaan, pelaksanaan, pertanggungjawabannya bisa diketahui publik dan rakayat berhak atas informasi faktual mengenai berbagai hal yang menyangkut pembuatan dan penerapan kebijakan. Ada 3 alasan pentingnya keterbukaan dalam penyelenggaraan pemerintahan:

1. Kekuasaan pada dasarnya cenderung diselewengkan.

2. Dasar penyelenggaraan pemerintahanh itu dari rakyat oleh rakyat dan untuk rakyat, agar penyelenggaraan pememrintahan itu tetap dijalur yang benar untuk kesejahteraan rakyat.

3. Dengan keterbukaan memungkinkan adanya akses bebas bebas warganegara terhadap informasi yang pada gilirannya akan memiliki pemahaman yang jernih sehingga mampu berpartisipasi aktif dalam menciptakan pemerintahan yang konstruktif dan rasional.

Andi Mappiare menjelaskan, Keterbukaan (openness atau disclosure) pada konselor merupakan kualitas pribadi yang dapat disebut sebagai cara konselor mengungkapkan kesejatiannya. Sebagai suatu cara, keterbukaan sama pentingnya dengan kesejatian itu sendiri. Tamar Plitt Harpen dan David M. Roshenthal yang menemukan beberapa hasil penelitian dan pendapat pakar, mengungkapkan bahwa terdapat bukti-bukti signifikan dalam literature untuk mendukung anggapan bahwa

\footnotetext{
${ }^{1}$ Abustan, Relasi Lembaga Negara Dalam Perspektif Undang Undang Dasar Negara Republik Indonesia 1945, Jurnal Unifikasi, Issn 2354-5976, E-Issn 2580-7382 Vol. o4 Nomor o2 Juli 2017
} 
Logika : Journal of Multidisciplinary Studies, p-ISSN 2085-9970. e-ISSN 2715-4505

Vol. 10 Nomor 02 Desember 2019. 94-99

keterbukaan diri dapat menimbulkan keterbukaan pada orang lain. Kemudian ditambahkan bahwa pengungkapan diri secara verbal pihak konselor akan mempermudah proses terapeutik.

Keterbukaan berarti memeberi peluang luar untuk masuk, dan menerima berbagai hal untuk masuk, baik itu d bidang ilmu pengetahuan, teknologi dan kebudayaan, ideology, paham dan aliran, ataupun ekonomi. Terbuka menerima kritik, saran, dan pendapat orang lain dlam pergaulan. Tidak menutup diri dari pergaulan, keterbukaan dan keterusterangan terhadp apa yang dipikirkan, diinginkan, diketahui dan kesediaan menerima saran dan kritik dari orang lain.

Keterbukaan juga dapat diartikan sebagai keadaan yang memungkinkan ketersediaan informasi yang dapat diberikan dan didapatkan oleh masyarakat luas. Dengan keterbukaan berarti seseorang pribadi atau pemerintah atau penyelenggara Negara sanggup bertanggung jawab terhadap kegiatan yang dilakukannya kepada masyarakat. Keterbukaan merupakan kondisi yang memungkinkan kondisi partisipasi masyarakat dalam kehidupan bernegara. Suasana keterbukaan juga dimaksudkan sebagai keterbukaan dalam berbagai bidang kehidupan, antara lain dalam iklim politik, yakni setiap warag Negara berhak mengemukakan pendapatnya sejauh tidak bertentangan dengan semangat Pancasila dan Undang-Undang Dasar 1945. Peraturan yang mengatur yaitu Undang-undang RI No. 28 tahun 1999 tentang asas umum penyelenggaraan negara dan Undang-undang No. 14 tentang Keterbukaan informasi publik.

Ciri-ciri Keterbukaan Sikap terbuka dalam kehidupan perlu ditumbuhkembangkan, mulai dari keluarga, masyarakat dan Negara. Adapun ciri-ciri keterbukaan dalam kehidupan sehari-hari adalah sebagai berikut ${ }^{2}$ :

1. Demokratis

2. Berkeadilan

3. Musyawarah dan mufakat

4. Berpikir luas dengan hati yang terbuka

5. Berani mengakui kesalahan

Fungsi Keterbukaan, Keterbukaan sangat penting dalam berkomunikasi. Sikap keterbukaan di antara kita akan dapat melancarkan informasi, dan pada akhirnya akan dapat memperkukuh persatuan dan kesatuan bangsa. Dengan keterbukaan itu, kita akan dapat menyerap berbagai kelebihan dan kekurangan yang kita miliki. Dan dengan itu pula kita akan bersikap dan berperilaku mau menghargai perbedaan yang dimiliki oleh orang, kelompok, atau suku bangsa lain. Sikap keterbukaan juga akan dapat meningkatkan kualitas sumber daya manusia. Budi pekerti dalam hubungannya dengan penerapan sikap berbudi pekerti luhur, salah satu sasarannya membangun dan menumbuhkembangkan individu-individu yang berjiwa demokratis. Secara umum fungsi keterbukaan adalah:

1. Akan memperoleh berbagai informasi sehingga dapat memperkaya pengetahuan

\footnotetext{
2 Suwari Akhmaddhian, Asas-Asas dalam Penyelenggaraan Pemerintahan yang Baik untuk Mewujudkan Good Governace, Logika : Journal of Multidisciplinary Studies, ISSN 2085-9970. Vol. o9 Nomor o1 Juni 2018. 30-38.
} 
Logika : Journal of Multidisciplinary Studies, p-ISSN 2085-9970. e-ISSN 2715-4505

Vol. 10 Nomor 02 Desember 2019. 94-99

2. Dapat meningkatkan sumber daya manusia.

3. Mampu memberikan, menularkan informasi mengenai hal-hal yang bersifat dapat memperkukuh persatuan dan kesatuan bangsa.

4. Mampu menghalau dan mengantisipasi pihak-pihak yang ingin memecah belah persatuan dan kesatuan bangsa.

5. Memungkinkan adanya kebiasaan berdialog, baik antar suku bangsa, golongan, aliran maupun agama.

6. Dapat membentuk forum permusyawaratan baik antar suku bangsa, golongan, aliran maupun agama.

7. Menghindari diri dari fitnah, dan berprasangka negative.

Menurut Peraturan Pemerintah No 68 Tahun 1999 Tentang Tata Cara Pelaksanaan Peran Masyarakat Dalam Penyelenggaraan Negara dinyatakan bahwa yang dimaksud dengan peran serta masyarakat adalah peran aktif masyarakat untuk ikut serta mewujudkan penyelenggara Negara yang bersih dan berwibawa yang dilaksanakan dengan menaati norma hukum, moral dan sosial yang berlaku dalam masyarakat. Peran masyarakat dalam penyelenggaraan Negara untuk mewujudkkan penyelenggaraan Negara yang bersih dilaksanakan dalam bentuk :

1. Hak mencari, memperoleh dan memberikan informasi mengenai penyelenggaraan Negara.

2. Hak untuk memperoleh pelayanan yang sama dan adil dari penyelenggara Negara.

3. Hak menyampaikan saran dan pendapat secara bertanggung jawab terhadap kebijakan penyelenggara Negara.

4. Hak memperoleh perlindungan hukum.

Kasus Bank Century merupakan tragedi kebangkrutan terbesar dalam ranah perbankan di Indonesia pada tahun 2009. Pemerintah terpaksa melakukan bail out 6.7 triliun rupiah untuk menyelamatkan likuiditas Bank Century. Dimana keputusan penyelamatan berasal dari permintaan Bank Indonesia karena dapat berdampak sistemik dengan menyeret 23 bank lainnya. Kasus bermula dari dugaan penyelewengan dana nasabah oleh Antaboga Sekuritas sebagai pemegang 7.52\% saham Bank Century dalam permainan instrumen derivatif. Kasus penyelewengan dana tersebut berkembang ke arah missmanagement yang dilakukan oleh pengelola DPK (dana pihak ketiga) Bank Century. Mencuatnya kasus Bank Century sering dikaitkan dengan dampak krisis global yang menerpa lembaga keuangan dunia dan berdampak sistemik pada perbankan Indonesia. Namun olah data badan penyidik keuangan (BPK) menemukan bahwa kasus Bank Century sudah terendus sebelum krisis global terjadi. Hal ini menimbulkan kecurigaan adanya pengalihan isu, sehingga para nasabah dan investor menjadi maklum dengan kasus likuiditas akibat efek krisis global yang berdampak pada Bank Century. Terjadi force majeur krisis dalam bentuk pembodohan opini publik. Hal ini dikuatkan oleh hasil penyidikan BPK yang menyebutkan bahwa Bank Century sudah cacat dari lahir. Berdasar hal tersebut, nampaknya Bank Century sejak dulu sampai diambil LPS selalu melanggar aturan, dimana pelanggaran yang terjadi berupa tingkat minimum CAR (Rasio 
Logika : Journal of Multidisciplinary Studies, p-ISSN 2085-9970. e-ISSN 2715-4505

Vol. 10 Nomor 02 Desember 2019. 94-99

kecukupan modal), batas maksimal pemberian kredit, dan FPJP (Fasilitas Pinjaman Jangka Pendek).

Dilihat dari kronologis kasus Bank Century, hal yang perlu di garis bawahi adalah praktik FPJP yang cenderung menetapkan bunga pinjaman di atas bunga yang berlaku di pasar. Dengan suku bunga kredit yang tinggi, jumlah default (gagal bayar) yang terjadi pun meningkat. Hal ini menjadikan NPL(non-performing loan) bank Century berada di atas level normal NPL perbankan pada umumnya. Jika kita menganalisis FPJP secara mendetail, hal ini sama dengan skema subprime mortgage. Bank menetapkan bunga yang tinggi untuk mendapatkan return yang tinggi tanpa memperdulikan kreditor yang belum tentu dapat membayar pokok ditambah bunganya. Selain faktor suku bunga dan pinjaman jangka pendek yang irrasional dan beresiko tinggi, manajemen Bank Century juga terbuktibersalah karena menggunakan dana nasabah untuk berinvestasi dalam instrumen derivatif, bukan disalurkan ke pembiayaan sektor riil. Instrumen derivatif merupakan instrumen yang penuh dengan permainan spekulasi. Setiap bank tentu mengharapkan return yang tinggi, namun cara yang dilakukan Bank Century merugikan nasabah. Hal tersebut sama saja menzalimi pihak nasabah karena tidak terdapat transparansi dalam usaha yang dijalankan. Nasabah dijanjikan imbal hasil (return) yang tinggi dan janji-janji yang terlalu menggiurkan dari pihak perbankan tanpa memberi informasi yang jelas tentang aliran pemanfaatan dananya. Kasus Bank Century juga digolongkan penipuan. Penipuan bermula dari sisi manajerial bank dengan ditemukan adanya praktik moral hazard. Hal ini timbul karena kurangnya pengawasan dari BI dan rendahnya etika serta moral para eksekutifnya. ${ }^{3}$

\section{SIMPULAN}

Berdasrkan penjelasan di atas keterbukaan sangat diperlukan dalam segala aspek kehidupan, baik dalam kehidupan berumah tangga, dalam organisasi sekecil apapun haruslah memiliki asas keterbukaan agar ada kepercayaan dari yang memimpin dengan pemimpinnya. Keterbukaan merupakan sikap bijak, rendah hati, adil, menerima pendapat oramng lain, memaafkan kesalahan orang lain dengan lapang dada, bertoleransi, tattwamasi, melakukan sesuatu yang sesuai dengan apa yang dinikmati dan dikatakannya

\section{SARAN}

Keterbukaan juga diperlukan untuk menciptakan rasa keharmonisan dalam kehidupan bermasyarakat karena dengan keterbukaan sesorang akan mau menerima segala sesuatu kelebihan yang dimiliki oleh orang lain dan tidak akan menganggap orang lain tersebut selalu ada di bawahnya.

3Gios Adhyaksa, Januari 2015, "Perlindungan Hukum Bagi Nasabah Terhadap Kerugian Akibat Pengalihan Asset Berdasarkan Prinsip Penyikapan Tabir Perseroan (Piercing The Corporate Veil) Dalam Kaitannya Dengan Pertanggung Jawaban Komisaris (Studi PT. Bank Century.,Tbk), vol.2 no.1, hlm. 7 
Logika : Journal of Multidisciplinary Studies, p-ISSN 2085-9970. e-ISSN 2715-4505

Vol. 10 Nomor 02 Desember 2019. 94-99

\section{DAFTAR PUSTAKA}

Abustan, Relasi Lembaga Negara Dalam Perspektif Undang Undang Dasar Negara Republik Indonesia 1945, Jurnal Unifikasi, Issn 2354-5976, E-Issn 2580-7382 Vol. 04 Nomor 02 Juli 2017

Gios Adhyaksa, Januari 2015, "Perlindungan Hukum Bagi Nasabah Terhadap Kerugian Akibat Pengalihan Asset Berdasarkan Prinsip Penyikapan Tabir Perseroan (Piercing The Corporate Veil) Dalam Kaitannya Dengan Pertanggung Jawaban Komisaris (Studi PT. Bank Century.,Tbk), vol.2 no.1

Suwari Akhmaddhian, Asas-Asas dalam Penyelenggaraan Pemerintahan yang Baik untuk Mewujudkan Good Governace, Logika : Journal of Multidisciplinary Studies, ISSN 2085-9970. Vol. o9 Nomor o1 Juni 2018. 30-38.

Undang-undang RI No. 28 tahun 1999 tentang Asas Umum Penyelenggaraan Negara.

Undang-undang No. 14 tentang Keterbukaan Informasi Publik 